\title{
ASSOCIATION NEWS
}

National days: All the national days were observed with due importance. International mother language day (21 February) - observed with fervor; 99th birth anniversary of Bangabandhu (17 March) - observed with honour; National genocide day (25 March) - observed with grief; Independence day (26 March) - celebrated with rejoice; Bangali new year (14 April) - celebrated with festivities; National mourning day (15 August) - observed with respect; Shahid Dr Milon day (27 November) - observed with gratitude; Intellectual martyrs day (14 December) - observed with reverence; Victory day (16 December) - celebrated with jubilation.

Commemoration: Successive meetings were arranged on the following days in the remembrance of the distinguished departed doctors for their deeds and contribution in the association.

02 June - Dr MA Manaf, Former reverend Editor of Bangladesh Medical Journal (Khulna Branch) 18 November - Dr Md Shamsur Rahman, Former President \& General Secretary of BMA(KB) 02 December - Dr Sd Munir Ahmed, One of the founder and past General Secretary of BMA (KB)

Publications: A life history on Shahid Dr Md Yasin 'Satata Samujjal' was published and the cover of the book was opened in a ceremony on 13 February by the Honorable Minister for Social Affairs - Rashed Khan Menon.

Scientific seminar: Seminar on different topics was held on the following days of the year with key note speakers mentioned against each of the topics.

02 February - Focus on individualized Medicine: Vitamin D Deficiency as an ignored epidemic Dr Vincenzo Costigliola (President of European Medical Association) \& Prof SR Karim.

16 February - A ground breaking innovation for type 2 Diabetes management - Dr DK Ghosh. 27 April - Management of Bronchial Asthma in clinical practice - Dr KA Mollick 21 September - ENT emergencies: Hoarseness of voice - Prof SK Ballav \& Dr M Kamruzzaman 16 November - Good Medical Practice - Prof Sanwar Hossain (Eminent Surgeon \& Advisor to Square Hospital); Common cancer of Bangladesh: Management, prevention \& screening - Prof SA Hossain; Transradial approach to coronary angiography \& Intervention - Dr M Mansur.

Professional interest: A protest was demonstrated for the insultation and manhandling of a lady doctor in the emergency department of City Medical College and two other doctors of Fakirhat Upazilla Health Complex. A case was filed on ICT laws in Shahbag thana for uploading humiliating words in social media against doctors in connection with a trivial matter in Rajshahi Medical College. More than a hundred doctors from Khulna under the leadership of BMA attended the conference (07 October) in Ganavaban, called on by Prime Minister. Our long cherished fifteen point demands were presented to the PM through the Secretary General.

Social welfare: Free medical service is rendered to the marginalized people through Binodini Memorial Hospital since 1962. In addition, 400 people with eye disease were served in this year free of cost by way of Eye camp.

Organizational function: Six EC meeting and four emergency meeting was held and important decisions on different issues were taken in the meeting. 